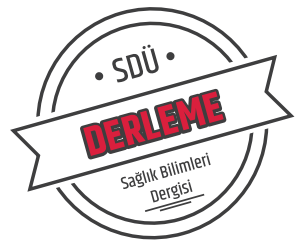

Sdü Sağlık Bilimleri Enstitüsü Dergisi / Cilt 8 Sayı 3 / 2017

\title{
Kemomekanik Çürük Uzaklaştırma Yöntemleri ve Etkinliklerinin \\ Değerlendirilmesi
}

Chemomechanical Caries Removal Methods and Their Efficacy

Günseli Katırcı' ${ }^{1}, \mathbf{R}$. Banu Ermiş ${ }^{1}$
${ }^{1}$ Süleyman Demirel Üniversitesi Diş Hekimliği Fakültesi, Restoratif Diş Tedavisi Anabilim Dalı, Isparta, Türkiye.

\section{Özet}

Günümüzde çürük dokusunun uzaklaştırılması için kullanılan yöntemler; döner aletler (frezler) veya ekskavatör, air abrazyon, ultrasonikler ve sonoabrazyon ile yapılan mekanik çürük uzaklaştırma yöntemleri, kemomekanik ve fotoablasyon (lazerler) çürük uzaklaştırma yöntemleri olmak üzere farklı kategorilerde sinıflandırılmaktadır. Konvansiyonel çürük uzaklaştırma yöntemleri etkin olmakla birlikte mevcut olan bazı dezavantajlarını önlemek amacıyla kemomekanik çürük uzaklaştırma yöntemleri geliştirilmiştir. Kemomekanik çürük uzaklaştırma yönteminin çalışma mekanizması, çürük dokusunun kimyasal yapısını değiştiren ve dokunun yumuşatılarak uzaklaştırılmasını sağlayan bir ajanın kullanılması ve yumuşayarak yapısı değişen dentin dokusunun mekanik olarak el aletleri ile uzaklaştırılması esasına dayanmaktadır. Kemomekanik çürük uzaklaştırma yönteminin, çürük dokusunu ağrısız bir şekilde sağlam diş sert dokularının kaybına yol açmadan sadece enfekte dentin tabakasını ve selektif olarak uzaklaştırdı ğ Ayrıca yöntemin bakterisit ve bakteriostatik etkilerinin bulunması, kullanımı sırasında 1sı ve basınç oluşturmayarak pulpa üzerinde olumsuz etkiler meydana getirmemesi de alternatif bir çürük uzaklaştırma yöntemi olarak değerlendirilmesini sağlamaktadır. Bu çalışmanın amacı, sodyum hipoklorit ve enzim esaslı kemomekanik çürük uzaklaştırma ajanları hakkında bilgi verilmesidir. Yöntemin avantaj ve dezavantajları ve ayrıca çürük uzaklaştırma etkinliği; rezidüel çürük ve bakteri varlığı, dentinin mikrosertliği ve kimyasal yapısı açısından laboratuvar ve klinik araştırmalardan elde edilen bulgular eşliğinde incelenecektir.

Anahtar kelimeler: Carisolv, çürük uzaklaştırma yöntemleri, kemomekanik çürük uzaklaştırma, mikrosertlik

\section{Giriş}

Restoratif materyallerin diş sert dokularına bağlanabilme potansiyeli kavite preparasyonlarında kullanılan genel prensiplerin değişmesini sağlamıştır (1). Bu nedenle son yıllarda sağlam diş dokularının kavite preperasyonu sırasında çürükten koruma ve retansiyon sağlamak amacıyla genişletilmesi prensibi terk edilmiştir. Fakat bu durum çürük

\begin{abstract}
Current caries removal methods are classified in various categories including rotating instruments (burs) or excavator, mechanical methods performed by air abrasion, ultrasonic and sono-abrasion, chemomechanical and photoablation (lasers) methods. While conventional caries removal methods are effective, chemomechanical methods were developed to avoid from some possible disadvantages. The action mechanism of chemomechanical caries removal method is based on use of an solution to chemically alter caries tooth tissue to further soften it thus its easier removal. The altered dentine tissue is then mechanicallly removed with hand instruments. Chemomechanical method is claimed to remove caries tissue by only removing the infected dentine layer selectively without causing pain and intact hard tooth tissue loss. Furthermore, the bactericidal and bacteriostatic effects of the method and absence of potential deleterious effects to dental pulp due to heat and pressure make it to be considered as an alternative caries removal method. The aim of this study is to provide information about sodium hypochlorite and enzyme based chemomechanical caries removal agents. Advantages and disadvantages of the method as well as the caries removal efficacy will be examined together with the findings obtained from laboratory and clinical studies on the presence of residual caries and bacteria, micro-hardness and chemical structure of the dentine.
\end{abstract}

Keywords: Carisolv, caries removal techniques, chemomechanical caries removal, microhardness
DOI: 10.22312 /sdusbed. 377426

Müracaat tarihi: 30.11 .2016

Kabul tarihi: 27.04.2017 lezyonlarının başarılı bir şekilde tedavi edilebilmesi için uzaklaştırılması gereken diş sert dokusu miktarı konusundaki tereddütleri de beraberinde getirmiştir (2). Demineralize dentinin uzaklaştırılması sırasında karşılaşılan güçlük, çürük lezyonlarının nerede bittiğinin kesin olarak ayırt edilememesinden ve çürük teşhisinde kullanılan objektif bir yöntemin olmamasından kaynaklanmaktadır (2). Klinikte

\footnotetext{
Yazışma Adresi / Corresponding: Günsel Katırcı,

Süleyman Demirel Üniversitesi Dişhekimliği Fakültesi, Restoratif Diş Tedavisi Anabilim Dalı Doğu Kampüsü, 32260 Çünür, Isparta, Türkiye.

Tel: 02462118937

Fax: 02462370607

E-mail: gunselikatirci@sdu.edu.tr
} 
renk ve sertlik kriterlerini esas alarak görsel bir değerlendirme sağlayan konvansiyonel çürük belirleme yöntemi, dentindeki çürük lezyonunun derinliği ve miktarının ölçülmesinde başarılı değildir (2). Ayrıca dentin dokusundaki renk farklılıkları, klinisyene dentin tabakalarını doğru olarak ayırt etme imkanı vermemektedir (2).

Dentindeki çürük lezyonlarının konservatif olarak tedavisinde izlenen yol, dentin dokusundaki nekrotik ve enfekte alanların uzaklaştırılması ve daha derindeki dokuların korunması şeklindedir (3). Fusayama adlı araştırıcı (4) çürük dentin tabakasını iki kısımda incelemektedir. Dış kısımdaki enfekte dentin tabakası yüksek oranda bakteri içermektedir, remineralize olma özelliği yoktur ve uzaklaştırılmadır. İç kısımdaki çürükten etkilenmiş dentin tabakası ise kısmen demineralizedir, remineralize olma potansiyeli mevcuttur ve çürüğün uzaklaştırılması sırasında korunmalıdır $(4,5)$. $\mathrm{Bu}$ nedenle ideal bir çürük uzaklaştırma yönteminden, kavitedeki çürük dokusunu sağlam dokulardan ayırt ederek sadece enfekte dentin tabakasını uzaklaştırması ve çürükten etkilenmiş dentin tabakasını koruması beklenmektedir (6). Ayrıca ideal çürük uzaklaştırma yöntemi, kullanılması sırasında minimum basınç uygulanarak hastada ağrı oluşumuna ve dentin dokusunda vibrasyon ve 1sı artışına neden olmadan çürük dokusunu uzaklaştırmalı ve klinikte kullanımı kolay olmalıdır (6).

Günümüzde çürük dokusunun uzaklaştırılması için kullanılan yöntemler; döner aletler (frezler) veya ekskavatör, air abrazyon, ultrasonikler ve sono abrazyon ile yapilan mekanik çürük uzaklaştırma yöntemleri, kemomekanik ve fotoablasyon (lazerler) çürük uzaklaştırma yöntemleri olmak üzere farklı kategorilerde sınıflandırılmaktadır (7).

Konvansiyonel olarak çürük dokusu mekanik prensipler kullanılarak frezler veya keskin kenarlı el aletleriyle uzaklaştırılmaktadır. Bu yöntem etkin olmakla birlikte bazı dezavantajları da mevcuttur (8). Bu dezavantajlar; aletlerin kullanılması sırasında oluşan hasta memnuniyetsizliği, ağrı kontrolünü sağlayabilmek için lokal anestezi gerektirmesi ve pulpa üzerinde basınç ve 1sı oluşturmasından kaynaklanan etkilerdir $(9,10,11)$. Ayrıca frezler sıklıkla çürük dokusu ile birlikte sağlam diş sert dokularının da uzaklaştırılarak diş yapılarının zayıflamasına sebep olabilmektedir (12).

$\mathrm{Bu}$ dezavantajları önlemek amacıyla konvansiyonel çürük uzaklaştırma yöntemlerine alternatif olarak kemomekanik çürük uzaklaştırma yöntemleri geliştirilmiştir (12). Kemomekanik çürük uzaklaştırma yönteminin çalışma mekanizması, çürük dokusunun kimyasal yapısını değiştiren ve dokunun yumuşatılarak uzaklaştırılmasını sağlayan bir ajanın kullanılması esasına dayanmaktadır. Yumuşayarak yapısı değişen dentin dokusu, mekanik olarak el aletleri ile uzaklaştırılmaktadır $(13,14)$. Kemomekanik çürük uzaklaştırma yönteminin, çürük dokusunu ağrısız bir şekilde ve selektif olarak yani sağlam diş sert dokularının kaybına yol açmadan sadece enfekte dentin tabakasını uzaklaştırdığı iddia edilmektedir (15). Ayrıca yöntemin bakterisit ve bakteriostatik etkilerinin bulunması, kullanımı sırasında 1S1 ve basınç oluşturmayarak pulpa üzerinde olumsuz etkiler meydana getirmemesi de alternatif bir çürük uzaklaştırma yöntemi olarak değerlendirilmesini sağlamaktadır $(6,14)$.

$\mathrm{Bu}$ derlemenin amacı; kemomekanik çürük uzaklaştırma ajanları ve yöntemin diş sert dokuları üzerindeki etkisi hakkında bilgi verilmesi ve ayrıca yöntemin etkinliğini araştıran laboratuvar ve klinik araştırmalardan elde edilen bulguların değerlendirilmesidir.

\section{Kemomekanik Çürük Uzaklaştırma Ajanları}

Kemomekanik çürük uzaklaştırma yöntemi ile birlikte kullanılan ajanlar, sodyum hipoklorit esaslı ve enzim esaslı materyaller olmak üzere ikiye ayrılmaktadır.

\section{Sodyum hipoklorit esaslı kemomekanik çürük uzaklaştırma ajanları}

Sodyum hipoklorit esaslı kemomekanik çürük uzaklaştırma ajanları kaynağını sodyum hipoklorit türevlerinden almıştır. $\mathrm{Bu}$ ajanlar çürük dentin dokusundaki kısmen yapısı bozulmuş olan kolajendeki hidrojen bağlarının yıkılmasını ve klorlanmasını sağlayarak bu dokunun uzaklaştırılmasını kolaylaştırmaktır (13). Bu amaçla ilk olarak 1975 yılında, $\% 5$ 'lik sodyum hipoklorit kullanılmıştır fakat \%5'lik sodyum hipokloritin toksik olması ve çevredeki sağlam diş sert dokuları açısından zararlı etkilerinin bulunması nedeniyle yeni bir solüsyon geliştirilmiştir (16). GK-101 adı verilen bu yeni ajan $\% 5$ 'lik sodyum hipoklorite sodyum hidroksit, sodyum klorür ve glisin eklenerek oluşturulmuştur (16). GK-101'in geliştirildiği dönemlerde, adeziv materyallerin kullanımının yaygın olmaması ve dişhekimlerinin hala Black prensiplerine göre kavite açma zorunluluğu, bu ajan ile birlikte geleneksel preparasyon yöntemlerinin de kullanılmasını gerektirdiğinden materyalin çürük uzaklaştırmadaki kullanımı sınırlı kalmıştır (16).

Diğer bir kimyasal ajan olan Caridex, monokloroglisin ve amino bütirik asit kullanılarak elde edilmiştir. Caridex, çürük dentindeki kollagenin yıkılmasını sağlayarak çürüğün kolaylıkla uzaklaştırılmasını sağlamaktadır. Fakat pahalı olması, bir seferde kullanılan solüsyon miktarının fazla olması ve raf ömrünün kısa olması gibi nedenler ile ajanın klinikte kullanımı sınırlı kalmıştır (6).

Günümüzde dental marketteki yerini halen koruyan bir diğer kemomekanik çürük uzaklaştırma ajanı olan Carisolv adlı materyal 1989 yılında İsveç'de geliştirilmiştir (17). Carisolv'ün diğer kemomekanik çürük uzaklaştırma ajanlarından en önemli farkı, yapısında amino bütirik asit yerine lösin, lizin ve glutamik asitten oluşan üç adet amino asidin bulunmasıdır. Bu amino asitler, sodyum hipokloritin sağlıklı ağı dokularında oluşturduğu agresif etkileri ortadan kaldırmaktadır (6). Amino asitler ve sodyum hipoklorit, kullanımdan önce eşit miktarlarda oda sıcaklığında karıştırılarak çürük dokusuna uygulanmaktadır. Karıştırılmış olan solüsyonun pH'sı yaklaşık 11 civarındadır (6). Jel ve likitin karıştırılması, hipokloritin yapısındaki klor atomunun her üç amino asitteki amino grubuna transfer olmasına ve kloraminlerin oluşmasına neden olmaktadır. Birbirinden farklı elektrik yüküne sahip olan amino asitler bu özellikleri sayesinde çürük dentinin yapısındaki proteinlerin farklı bölgelerine bağlanmaktadır (12). 
Yapısı çürük nedeniyle bozulmuş olan kolajenin kloraminlerle yıkılmaya elverişli bir yapısı vardır. Demineralize dentinin pöröz yapısı da ajanın dentine penetre olmasını kolaylaştırmaktadır. Çürükten etkilenmemiş olan kolajen yapısal bozulmalara karşı direnç gösterirken pöröz mineral yapı içerisindeki yapısı bozulmuş olan kolajen ağı kolaylıkla yıkılır ve uzaklaştırılabilir (12). Jelin uygulanması sırasında sodyum hipokloritin ve amino asitlerin karıștırılmasıyla elde edilen N-mono-kloroamino asitin, çürük dentindeki yapısı bozulmuş olan kolajenin parçalanmasına neden olarak ortamdan uzaklaştırdığı iddia edilmektedir (18). Jelin çürük dokusu üzerine uygulanması el aletleri için de mekanik lubrikant etkisi sağlayarak çürük dentinin uzaklaştırılmasını kolaylaştırır (6). Carisolv ile birlikte kullanılan özel el aletleri keskin kenarlıdır, diş sert dokularını kesmek yerine kazıma amacına yönelik olarak tasarlanmıştır (12).

Carisolv'ün çürük uzaklaştırmadaki etkinliğinin bildirilmesine ve özellikle handikaplı çocuk hastalarda kullanılması önerilmesine rağmen uzun çalışma zamanı, materyalin maliyetinin artmasına neden olan özel el aletleriyle birlikte kullanılması ve çürük dentine ulaşabilmek için minenin uzaklaştırılması amacıyla geleneksel döner aletlerin kullanımını gerektirmesi gibi dezavantajları vardır $(6,10)$.

\section{Enzim esaslı kemomekanik çürük uzaklaștırma ajanları}

Son yıllarda geliştirilen ve dental markette yerini alan bir kemomekanik çürük uzaklaştırma ajanı Papacarie adıyla bilinmektedir. Bussodori ve arkadaşları (10) tarafından 2003 yılında geliştirilmiş olan bu ajan; papain enzimi, kloramin, toluidin mavisi, çeşitli tuzlar, koruyucu, stabilizatör, kıvam artırıcı ve deiyonize su içermektedir $(10,13)$. Proteolitik bir enzim olan ve bakterisit, bakteriostatik ve antienflamatuar etkileri bulunan papain; Brezilya, Hindistan, Güney Amerika ve Havai'de yetişen yeşil olgun papaya yapraklarından ve sıvılarından elde edilmektedir (10). Kloramin, yapısı bozulmuş dokuları uzaklaştırmak amacıyla bu jelin içine eklenmiştir (13).

Enzim esaslı çürük uzaklaştırma ajanlarının etki mekanizması tam olarak bilinmemektedir (13). Bununla birlikte, papainin selektif bir şekilde çürük dentin dokusundaki kısmen yapısı bozulmuş olan kolajen moleküllerinin çözülmesini sağladığ 1 bildirilmiştir (10). Çürük dokusuna uygulandıktan sonra ise yumuşamış olan enfekte dentin dokusunun, kesme işlemi yapmadan, basınçsız bir şekilde, keskin olmayan bir ekskavatörle uzaklaştırılması tavsiye edilmektedir (13).

Papacarie'nin enfekte dentin dokusunu etkin bir şekilde uzaklaştırması, uygulanması sırasında hastada minimum düzeyde ağrı ve rahatsızlık hissi oluşturması, antibakteriyel etkisinin bulunması, manüplasyonunun kolay olması ve ucuz olması, avantajları arasında sayılabilmektedir $(10,19)$.

Carie Care, etken maddesinin kaynağı papaya özütü olan, diğer bir papain enzimi esaslı kemomekanik çürük uzaklaştırma ajanıdır. Ayrıca bir endoprotein, kloramin, boya maddesi ve bitkisel kaynaklı esansiyel yağlar içermektedir (20). Bu esansiyel yağlar, antienflamatuvar ve hafif düzeyde anestezik etki göstermektedir. Carie Care, uygulandığı çürük dokusundaki enfekte dentini yumuşatırken anti-enflamatuvar aktivite oluşturmaktadır. Ayrıca aromatik bir tat içerdiği iddia edilmektedir (20). Jel, kavitede uygulandığ çürük diş dokusunda renk değişikliği oluşturmaktadır ve bu enfekte alan keskin kaşık şeklindeki bir ekskavatör ile uzaklaştırılmaktadır. $\mathrm{Bu}$ materyalin, geleneksel çürük uzaklaştırma metodunun henüz yerini almamakla beraber, anksiyete düzeyi yüksek çocuk hastalarda diğer çürük uzaklaştırma metotlarına alternatif oluşturabileceği iddia edilmektedir (20).

Biosolv (SFC-V ve SFC-VIII), deneysel bir enzim esaslı kemomekanik çürük uzaklaştırma ajanıdır. Biosolv jeli, bir fosforik asit ve sodyum biyofosfat ile tamponlanmış pepsin enzimi içermektedir. Jelin içeriğindeki pepsinin çürükle enfekte olmuş dentin dokusundaki yapısı bozulmuş olan kolajen fibrilleri selektif olarak yıkıma uğratırken, içeriğindeki fosforik asidin de inorganik yapının çözülmesini sağladığı iddia edilmektedir. Böylece yumuşamış olan dentin dokusu, jel için özel olarak dizayn edilmiş olan plastik el aletleri ile sağlam diş sert dokularına zarar vermeden kolayca uzaklaştırılabilmektedir (13).

Günümüzde Biosolv kullanılarak yapılan çalıșmalardan elde edilen bulgular sınırlıdır. Bir çalışmada, Biosolv'un çürükle enfekte olmuş dentin dokusunu Carisolv'den daha etkin bir şekilde uzaklaştırdığını iddia etmektedir (13). Bir başka çalışmada ise, Biosolv’un asidik yapısından dolayı agresif bir kemomemekanik çürük uzaklaştırma ajanı olduğunu ve ayrıca materyalin çürük dentin dokusu ile birlikte sağlam dentin dokusunu da uzaklaştırdığını belirtmektedir (13). Bu ajanın klinikte rutin bir şekilde kullanılabilmesi için, çürük uzaklaştırma etkisinin ve mekanizmasının anlaşılmasını sağlayacak daha fazla araştırmaya gerek vardır (13).

\section{Kemomekanik Yöntemin Çürük Uzaklaştırma Etkinliğinin Değerlendirilmesi}

Kemomekanik yöntemin etkinliği, kavitede kalan çürük dentin oranı, dentin kanallarında bakteri varlığı, çürük uzaklaştırıldıktan sonra kalan dentin dokusunun sertliği, kimyasal ve morfolojik yapısı, tedavi süresi ve lokal anestesi ihtiyacı gibi farklı açılardan hem laboratuvar hem de klinik araştırmalar ile değerlendirilmiştir.

\section{Rezidüel çürük ve bakteri varlığının değerlendirilmesi}

Kemomekanik yöntemin etkinliği sıklıkla, çürük temizlendikten sonra kavitenin rezidüel çürük dentin varlığı açısından histolojik olarak incelenmesi ile değerlendirilmiştir. Carisolv kemomekanik ajanı ile yapılan çürük uzaklaştırma işleminin konvansiyonel döner aletler (karbit frezler) ile yapılan çürük uzaklaştırma işlemi kadar etkili olmadığı ve kavitelerin \%20'sinde çürük dentin kaldığını rapor eden araştırmalar mevcuttur (21,22,23). Bazı araştırmalarda kemomekanik yöntemin kullanıldığı kavitelerde kalan rezidüel çürüğün bir kısmının mine-dentin sınırında lokalize olduğuna dikkat çekilmiştir. Bu nedenle yöntem ile başarılı sonuçlar elde etmek için kavitenin yeterli genişlikte açılması ve çürüğü örten mine kenarlarının kaldırılması gerektiği önerilmiştir $(12,24)$. Bunun yanında farklı çürük uzaklaştırma yöntemlerinin etkinliğinin lazer taramalı konfokal mikroskop kullanılarak karşılaştırıldığı bir çalışmada, Carisolv sistemi ile ekskavatörlerin daimi dişlerdeki dentin çürüğünü benzer 
oranda, karbit frezler ile elde edilen sonucun aksine daha selektif olarak ve aynı zamanda etkin bir şekilde uzaklaştırdığı bildirilmiştir (25).

Son yıllarda farklı çürük uzaklaştırma yöntemlerinin etkinliği bilgisayarlı tomografi ile değerlendirilmekte ve çürük temizlendikten sonra kavitede kalan rezidüel çürüğe ait kantitatif değerler elde edilebilmektedir. Metal ekskavatörler ile birlikte ve Carisolv, deneysel SFC-V ve SFC-VIII kullanılarak yapılan kemomekanik çürük uzaklaştırma işleminin çürüğün uzaklaştırılmasında en selektif yöntem olduğu sonucuna varılmıştır (26). Ayrıca karbit frezler ile yapılan konvansiyonel çürük uzaklaştırma işleminin dişlerde aşırı madde kaybına neden olabileceği buna karşın sağlam diş yapılarının maksimum oranda korunduğu yöntemin kemomekanik çürük uzaklaştırma yöntemi olduğu bildirilmiştir $(26,27)$.

Farklı çürük uzaklaştırma yöntemlerinin daimi dişlerdeki etkinliğinin klinik çalışmalar ile değerlendirildiği ve rezidüel çürük varlığının renk ve sertlik kriterlerine göre saptandığ1 çalışmalarda, Carisolv’ün çürük uzaklaştırma etkinliği \%99 olarak rapor edilmiştir (28). Munshi ve arkadaşları (Munshi AK, 2001), çürük dokusunun Carisolv ile uzaklaştırıldığı dişlerin altı ay sonraki radyografik kontrollerinde sekonder çürüğe rastlamadıklarını bildirmişlerdir (29).

Kemomekanik çürük uzaklaştırma yönteminin etkinliği, histolojik olarak çürük temizlendikten sonra dentin kanallarında kalan rezidüel bakteri varlığı açısından da değerlendirilmiştir. Söz konusu bu çalışmalarda, en çok rezidüel bakteriye kemomekanik yöntemin kullanıldığı gruplarda rastlanmıştır. Histolojik incelemeler sonucunda, Carisolv'un kullanımından sonra dentin tübüllerinde saptanan reziüel bakteri oranı \%47-64 olarak bildirilmiştir (12,24,30). Daimi molar dişlerdeki oklüzal çürük lezyonlarının uzaklaştırılmasında farklı yöntemlerin karşılaştırıldığı diğer in vitro çalışmalarda, kemomekanik yöntem (Carisolv, Papacarie) ve çelik frez kullanıldıktan sonra bakteri veya bakteriyel deposit içeren dentin kanallarının mikroskobik olarak tespit edildiği örneklerin sayısı arasında fark bulunmamıştır $(31,32)$.

\section{Dentinin mikrosertliği ve kimyasal yapısının değerlendirilmesi}

Çürük dentin dokusunun sertlik derecesinin, dokudaki enfeksiyon miktarı ile ilişkili olduğu, yumuşak ve enfekte dentin dokusu ile minimal düzeyde enfeksiyon içeren fakat sert dentin dokusunu klinik olarak ayırt etme imkanı sağladığı düşünülmektedir (33). Bu nedenle farklı çürük uzaklaştırma yöntemlerinin etkinliği, çürük temizlendikten sonra kavitede kalan dentinin mikrosertliğinin ve enerji dağılımlı X-1şını spektroskopisi (SEM-EDS) yöntemi kullanılarak diş sert dokularının inorganik yapısındaki kalsiyum $(\mathrm{Ca})$ ve fosfor (P) miktarının analiz edilmesi ile değerlendirilmektedir (7,8,20,34,35,36,37).

Çürük daimi dişlerde yapılan in vitro çalışmalarda, konvansiyonel olarak ekskavatörler veya frezler ile çürük temizlendikten sonra kavitede kalan dentin dokusunun mikrosertlik değerinin, kemomekanik yöntemin kullanıldığ dişlerden istatistiksel olarak anlamlı düzeyde daha yüksek olduğu saptanmıştır $(7,8,36)$. Bu sonuç, konvansiyonel ekskavasyondan sonra daha sert dentin dokusu bırakıldığını veya başka bir deyişle kemomekanik ekskavasyondan sonra kavitede daha fazla demineralize dentin dokusu kaldığını göstermektedir (7,8,36). Hamama ve arkadaşları (36), konvansiyonel çürük temizleme işleminden sonra kavite tabanının 25, 50, 75 ve 100 mikron altındaki bölgelerden yaptıkları ölçümlerde dentin mikrosertlik değerinin çok fazla değişmediğini ve bunun frez ile yapılan ekskavasyonun hem enfekte hem de etkilenmiş dentini uzaklaştırarak sağlam dentinde sonlandığını gösterdiğini rapor etmişlerdir. Aynı çalışmada Carisolv ve Papacarie ile yapılan ekskavasyondan sonra dentin mikrosertlik değerinin dereceli olarak azaldığ1 gösterilmiş ve bu da çürüğün kemomekanik olarak temizlendiği kavitelerde çürükten etkilenmiş dentinin korunduğu şeklinde yorumlanmıştır (36).

In vitro çalışmalarda kemomekanik çürük temizleme işleminin sağlam dentin yapısına herhangi bir olumsuz etkisinin olup olmayacağı da değerlendirilmiş, Carisolv ve Carie-Care ile çürük uzaklaştırıldıktan sonra kavitede kalan dentin ile aynı dişteki sağlam dentin dokusunun mikrosertlik değerleri arasında fark olmadığ 1 rapor edilmiştir (34,37).

Ayrıca çeşitli araştırmalarda Carisolv ve Papacarie uygulamasindan sonra yapılan SEM-EDS analizlerinde, kavitede kalan dentin ile sağlıklı dentin bölgesi arasında ağırlıkça $\mathrm{Ca}, \mathrm{P}$ miktarı ve $\mathrm{Ca} / \mathrm{P}$ oranı açısından fark bulunmamıştır (34,35,36). Böylelikle kemomekanik çürük uzaklaştırma işleminin dentinin inorganik yapısal bileşenlerinde meydana getirdiği kimyasal değişikliklerin minimum olduğu, dentinin yapısı üzerinde herhangi bir olumsuz etkisi olmadığı, çürük dentinin temizlenmesinde etkili bir yöntem olduğu ve klinikte çürüğün tamamen uzaklaştırılıp uzaklaştırılmadığını gösteren uygun bir rehber varlığında kullanılmasının olumlu olacağı sonucuna varılmıştır $(34,35,36)$.

\section{Tedavi süresi ve hasta memnuniyeti}

Yapılan bir çok klinik çalışmada kemomekanik çürük uzaklaştırma yönteminin etkinliği, çürük dokusunun temizlenme süresinin konvansiyonel yöntemler ile karşılaştırılması ile de değerlendirilmiştir. Daimi ve süt dişlerinde kemomekanik yöntem ile yapılan çürük temizleme işleminin frezler ile yapılan işleme kıyasla daha uzun sürdüğü bildirilmiştir $(38,39,40)$. Kemomekanik yönteminin diğer çürük uzaklaştırma yöntemlerine göre çürük dokusunu daha uzun sürede uzaklaştırmasının, ekskavasyon sırasında kullanılan enstrümanların sıklıkla değiştirilmesi zorunluluğundan, ayrıca yöntem bir solüsyon uygulamasını gerektirdiğinden dolayı solüsyonun yıkanmasının ve ekskavasyonun tamamlanamadığı durumlarda prosedürün tekrarının zaman alıcı olmasından kaynaklandığı belirtilmiştir (31). Başka bir çalışmada, dentin çürüğünün uzaklaştırılma süresi açısından kemomekanik yöntem ve ekskavatör kullanılarak yapılan konvansiyonel yöntem arasında bir fark olmadığı saptanmıştır (41). Ayrıca araştırıcılar kemomekanik yöntem ile kök çürüklerinin, koronal dentin çürüklerinden 
daha uzun sürede ekskave edilebildiğini de gözlemişlerdir (41). Başka bir çalışmada ise, dentin dokusundaki durgun çürük lezyonlarının, yumuşak çürük lezyonlarından daha uzun sürede uzaklaştırıldığı bildirilmiştir (29). İki farklı kemomekanik ajan olan Papain ve Carisolv'un ise süt dişlerindeki dentin çürüğünü benzer sürelerde temizlediği rapor edilmiştir $(39,40)$.

Frez ile yapılan çürük temizleme işlemi sırasında gereken lokal anestezi işlemine, kemomekanik yöntem ile çürük temizlenmesi sırasında ihtiyaç duyulmaması bu yöntemin bir avantajı olarak gösterilmektedir. Farklı çalışmalarda süt dişlerinde kemomekanik yöntemin lokal anestezi gerektirmeden kullanılabileceği bildirilmiştir $(8,29,39)$. Ayrıca hem süt hem de daimi dişlerdeki çürük lezyonlarının dahil edildiği bir in vivo çalışmada Carisolv kullanılan hastaların sadece \%3'ünde lokal anestezi gerektiği ve hastaların çoğunun frez ile karşılaştırıldığında yöntemi daha az rahatsız edici bulduğu rapor edilmiştir (38). Bununla birlikte hastaların ajanın içeriğindeki klorun kokusundan ve tadından rahatsız olabildiği de gösterilmiştir $(28,38)$.

\section{Sonuç}

Kemomekanik çürük uzaklaştırma yönteminin, çürük dokusunu selektif olarak, sağlam diş sert dokularının kaybına yol açmadan sadece enfekte dentin tabakasını uzaklaştırması geleneksel yönteme alternatif oluşturması bakımından umut vericidir. Ayrıca kemomekanik yöntemin uygulanması sırasında hastada minimum düzeyde ağrı ve rahatsızlık hissi oluşturması, antibakteriyel etkisinin bulunması, geleneksel çürük uzaklaştırma metodunun henüz yerini almamakla beraber, anksiyete düzeyi yüksek çocuk hastalarda diğer çürük uzaklaştırma metotlarına alternatif oluşturabileceğini düşündürmektedir. Bununla birlikte uzun çalışma zamanı gerektirmesi, materyalin maliyetinin artmasına neden olan özel el aletleriyle birlikte kullanılması ve çürük dentine ulaşabilmek için minenin uzaklaştırılması amacıyla geleneksel döner aletlerin kullanımını gerektirmesi gibi dezavantajlarının bulunması yöntemle birlikte kullanılan solüsyonların daha fazla araştırma ile değerlendirilmesi gerektiğini düşündürmektedir.

\section{References}

1. Neves AA, Eduardo C, Cardoso MV, Van Meerbeek B. Current concepts and techniques for caries excavation and adhesion to residual dentin. J Adhes Dent 2011; 13 (1): 7-22.

2. Ziskind D, Kupietzky A, Beyt N. First-choice treatment alternatives for caries removal using the chemomechanical method. Quintessence Int 2005;36(1):9-14.

3. Nikiforuk G. The Caries Process-Morphological and Chemical events. In: Understanding Dental Caries 1 Etiology and Mechanism Basic and Clinical Aspects. Switzerland: Karger, 1985: 261-288.

4. Fusayama T. A Simple Pain-Free Adhesive Restorative System by Minimal Reduction and Total Etching. St Louis: Ishiyaku EuroAmerica Inc, 1993: 1-21.

5. Lai G, Zhu L, Xu X, Kunzelmann K-H. An in vitro comparison of fluorescence-aided caries excavation and conventional excavation by microhardness testing. Clin Oral Investig 2014; 18(2): 599-605.

6. Banerjee A, Watson FT, Kidd EAM. Dentine caries excavation: a review of current clinical techniques. Br Dent J 2000; 188(9): 476-482.

7. Boob RA, Manjula M, Reddy RE, Srilaxmi N, Rani T. Evaluotion of the efficiency and effectiveness of three minimaly invasive methods of caries removal: An in vitro study. J Clin Pediatr Dent 2014; 7(1):11-18.

8. Magalhães CS, Moreira AN, Campos WR, Rossi FM, Castilho GA, Ferreira RC. Effectiveness and efficiency of chemomechanical carious dentin removal. Braz Dent J 2006; 17(1): 63-7.

9. Kirzioglu Z, Gurbuz T, Yilmaz Y. Clinical evaluation of chemomechanical and mechanical caries removal: status of the restorations at 3, 6, 9 and 12 months. Clin Oral Investig 2007; 11(1): 69-76.

10. Bussadori SK, Castro LC, Galvão AC. Papain gel: a new chemo-mechanical caries removal agent. J Clin Pediatr Dent 2005; 30(2): 115-9.

11. Inglehart MR, Peters MC, Flamenbaum MH, Eboda NN, Feigal RJ. Chemomechanical caries removal in children: an operator's and pediatric patients' responses. J Am Dent Assoc 2007;138(1): 47-55.

12. Yazici AR, Atílla P, Ozgünaltay G, Müftüoglu S. In vitro comparison of the efficacy of Carisolv and conventional rotary instrument in caries removal. J Oral Rehabil 2003; 30(12): 1177-1182.

13. Hahama H, Yiu C, Burrow M. Current update of chemomechanical caries removal methods. Australian Dental Journal 2014; 59(4):446-456.

14. Maragakis MG, Hahn P, Hellwig E. Chemomechanical caries removal: a comprehensive rewiev of the literature. Int Dent J 2002; 51(4): 291-299

15. Kımar J, Nayak M, Prasad KL, Gupta N. A comparative study of the clinical efficiency of chemomechanical caries removal using Carisolv and Papacarie- A papain gel. Indian J of Dent Res 2012; 23(5) 697.

16. Goldman M, Kronman JH. A preliminary report on a chemomechanical means of removing caries. Am Dent Assoc 1976; 93(6): 1149-53.

17. Arvidsson A, Liedberg B, Möller K, Lyvén B, Sellén A, Wennerberg A. Chemical and topographical analyses of dentine surfaces after Carisolv treatment. J Dent 2002; 30(23): $67-75$.

18. Flückiger L, Waltimo T, Stich H, Lussi A. Comparison of chemomechanical caries removal using Carisolv or conventional hand excavation in deciduous teeth in vitro. $\mathrm{J}$ Dent 2005; 33(2): 87-90.

19. Mollica BF, Torres GRC, Gonçalves PES, Mancini GN. Dentine microhardness after different methods for detection and removal of carious dentine tissue. J Appl Oral Sci 2012; 20(4): 449-454. 
20. Venkataraghavan K, Kush A, Lakshminarayana CS, Diwakar L, Ravikumar P, Patil S, Karthik S. Chemomechanical caries removal: A review \& study of an Indigenously devoloped agent (Carie Care Gel) in children. Journal of International Oral Health 2013; 5(4): 84-90.

21. Splieth C, Rosin M, Gellissen B. Determination of residual dentine caries after conventional mechanical and chemomechanical caries removal with Carisolv. Clin Oral Investig 2001; 5(4): 250-3.

22. Gurbuz T, Yilmaz Y, Sengul F. Performance of laser fluorescence for residual caries detection in primary teeth. Eur J Dent 2008; 2(3): 176-84

23. Katırcı G, Farklı Çürük Uzaklaştırma Yöntemlerinin Etkinliklerinin İn Vitro Olarak Karşılaştırılması, Isparta: Süleyman Demirel Üniversitesi, 2009.

24. Cederlund A, Lindskog S, Blomlöf J. Efficacy of Carisolvassisted caries excavation. Int $\mathrm{J}$ Periodontics Restorative Dent 1999; 19(5): 464-9.

25. Banerjee A, Kidd EA, Watson TF. In vitro evaluation of five alternative methods of carious dentine excavation. Caries Res 2000; 34(2): 144-50.

26. Neves AA, Coutinho E, Munck DJ, Meerbeek VB. Cariesremoval effectiveness and minimal-invasiveness potential of caries-excavation techniques: A micro-CT investigation.

J Dent 2011; 39 (2): 154-162.

27. Zhang X, Tu R, Yin W, Zhou X, Li X, Hu D. Microcomputerized tomography assessment of fluorescence aided caries excavation (FACE) technology: comparison with three other caries removal techniques. Aust Dent J 2013; 58(4): 461-467.

28. Maragakis GM, Hahn P, Hellwig E. Clinical Evaluation of Chemomechanical Caries Removal in Primary Molars and Its Acceptance by Patients. Caries Res 2001; 35(3): 205-210.

29. Munshi AK, Hegde AM, Shetty PK. Clinical evaluation of Carisolv in the chemico-mechanical removal of carious dentin. J Clin Pediatr Dent 2001; 26(1): 49-54.

30. Peric T, Markovic D. In vitro effectiveness of a chemomechanical method for caries removal. Eur J Pediatr Dent 2007; 8(2): 61-67.

31. Lennon AM, Buchalla W, RasnerB, Becker K, Attin T. Efficiency of 4 Caries Excavation Methods Compared. Operative Dent. 2006; 31(5): 551-555
32. Divya G, Prasad GM, Vasa KAA, Vasanthi D, Ramanayana B, Mynampati P. Evaluation of the efficacy of caries removal using polymer bur, stainless steel bur, Carisolv, Papacarie An invitro comparative study. J Clin and Diagn Res. 2015; 9(7): 42-46.

33. Li R, Zhao Y, Ye L. How to make of the carious removal methods, Carisolv or traditional drilling? A meta-analysis. J Oral Rehabil 2014; 41(6): 432-442.

34. Hossain M, Nakamura Y, Tamaki Y, Yamada Y, Murakami $\mathrm{Y}$, Matsumoto $\mathrm{K}$ Atomic analysis and knoop hardness measurement of the cavity floor prepared by Er,Cr:YSGG laser irradiation in vitro. J Oral Rehabil 2003; 30(5): 515-21.

35. Sakoolnamarka R, Burrow MF, Swain M, Tyas MJ. Microhardness and $\mathrm{Ca}: \mathrm{P}$ ratio of carious and Carisolv treated caries-affected dentine using an ultra-microindentation system and energy dispersive analysis of x-rays-a pilot study. Aust Dent J 2005; 50(4): 246-250.

36. Hahama HH, Yiu CYK, Burrow MF, King NM. Chemical, morphological and microhardness changes of dentine after chemomechanical caries removal. Aust Dent J 2013; 58(3): 283-292.

37. Ramamoorthi S, Nivedhitha MS, Vanajassun PP. Effect of two different chemomechanical caries removal agents on dentin microhardness: An in vitro study. J Conserv Dent 2013; 16(5): 429-33.

38. Ericson D, Zimmerman M, Raber H, Götrick B, Bornstein $\mathrm{R}$, Thorell J. Clinical evaluation of efficacy and safety of a new method for chemo-mechanical removal of caries. A multi-centre study. Caries Res1999; 33(3): 171-7.

39. Bohari M, Chunawalla KY, Ahmed NMB. Clinical evaluation of caries removal in primary teeth using conventional, chemomechanical and laser technique: An in vivo study. J Contemp Dent Pract 2012; 13(1): 40-47.

40. Chowdhry S, Saha S, Samadi F, Jaiswal JN, Garg A, Chowdhry P. Recent vs Conventional Methods of Caries Removal: A Comparative in vivo Study in Pediatric Patients. Int J Clin Pediatr Dent 2015;8(1):6-11.

41. Nadanovsky P, Carneiro CF, Mello SF. Removal of Caries Using only Hand Instruments:A Comparison of Mechanical and Chemo-Mechanical Methods. Caries Res 2001; 35(5): 384-389. 